\section{Breach of trust in Sudan}

SIR - There has been a serious breach of the principles under which Sudanese biomedical scientists have participated in a long-standing programme of collaborative research on tropical parasitic diseases supported by the US National Institutes of Health (NIH) Programme on International Collaboration on Infectious Disease Research (ICIDR).

Sudanese and US scientists have cooperated in an exemplary way in this research since the beginning of the grant award in 1979. There have been many important jointly authored publications, and opportunities for the growth and development of Sudanese researchers. Recently, however, both the letter and spirit of the NIH ICIDR programme have been abused by administrative actions at Michigan State University, the US counterpart institution (1979-90).

Data and patient samples from our collaborative work were removed without authorization from the laboratory of the former programme director, Professor Jeffrey Williams, by a student whom he had dismissed. A manuscript based on these materials has been published (Trop. Med. Parasitol. 42, 79-81; 1991) and this plagiarism was condoned by university officials. The submission of this manuscript was approved despite our written protest at the highest administrative levels. Neither we nor our US co-investigators were allowed to see the manuscript before submission. The publication includes no acknowledgement of the support of our ICIDR grant, and no credit to the institutions that participated. No authorizations were ever solicited or granted for use of our data or any other intellectual or material contributions. This is totally unacceptable. Our interests as Sudanese scientists have been violated. This contemptuous act must be brought to the attention of the biomedical community at large.

While the NIH ICIDR programme has always been founded on the commonly accepted principles of scientific collaboration, specific provision has been made for the involvement of investigators from developing countries by the following NIH stipulation: "that publications resulting from the collaboration will be coauthored by the foreign scientists, and that the data will be made readily available to the government of the host country at all times (for example NIH, RFA 15 September 1987)". These conditions have not been honoured. Our efforts have been exploited.

Unprincipled violation of international agreements cannot be permitted to go on without public exposure, especially when the interests of tropical medical research scientists in developing countries have been compromised. Such resources are too scarce to be so mistreated. We believe those responsible should be called to account for their actions.

M. O. A. MALIK (Chairman, Medical Research Council*), Mohammed Hag ALI (Director, Medical Research Council), MAMOUN HOMEIDA (Director, Soba University Hospital), HASSAN M. ALI (Dean, Faculty of Pharmacy), HASHIM WARSAMA GHALIB (University of Juba), SUAD M. SUlEIMAN (Ministry of Health, Sudan), EL-HADI A. EL-SHEIKH (Khartoum Eye Hospital), OMER ZAYED (University of Khartoum Medical School) BABIKER MAHMOUD (School of Pharmacy) * PO Box 1304, Khartoum, Sudan.

\section{Cancer treatments}

SIR - Your Munich correspondent's account $^{1}$ of the foundation of our new centre for tumour biology is broadly correct, but his description of the centre's scientific aims was less careful. The nondiscriminating equation of alternative cancer treatment with quackery is premature. There is a wide consensus among oncologists that many conventional cancer treatments are inadequate and that new and innovative approaches are desirable. These approaches will necessarily be 'alternative' to the existing ones. Studies of the genetic basis of cancer, that is, insight into the identity and the mechanism of the action of oncogenes and tumour suppressor genes, will provide many opportunities in the years to come.

The first diagnostic applications are already being implemented. It is conceivable that cancer therapies will be designed that specifically exploit the activation of individual proto-oncogenes - for example, the interruption of specific growth factor receptor-ligand interactions or mitogenic signal transduction pathways triggered by activated receptors. Immunological approaches in which the body's defence against tumour cells is exogenously supported might become valuable; for example, antibodies and antibody chimaeras directed against epitopes with enhanced expression on tumour cell surfaces (c-erB-2 overexpression in breast and ovarian carcinomas) can be produced because of progress in genetic engineering. Recombined receptors may allow the direction of cytotoxic $\mathrm{T}$ cells against tumour cells. Plants may harbour valuable compounds that have not been adequately used or tested in oncogene research. The suppression of c-jun/AP-1 activity by curcumin (dietary pigment responsible for the yellow colour of curry) as the basis for the inhibition of PMA-induced tumour promotion on mouse skin might serve as an example 2 .

"Picking a path for the new clinic" may not be trivial, but will certainly be exciting in times of rapid progress in the understanding of cancer biology. A little benevolence towards this innovative enterprise from a scientific journal would probably not hurt.

BERND GRONER GERD A. NAGEL

Centre of Tumour Biology Freiburg,

PO Box 1120,

$D$-7800 Freiburg, Germany

1. Dickman, S. Nature 352, 95 (1991)

2. Huang, T. S., Lee, S. C. \& Lin J. K. Proc. natn Acad. Sci. U.S.A. 88, 5292-5296 (1991)

\section{Cover story}

SIR - In order that the receipt of individual periodicals issues can be accurately and precisely recorded, it is helpful if all the essential information can be displayed on the outside front cover. When faced with a pile of periodicals to be recorded, it is exasperating for the librarian to have to open up the issue to retrieve essential information. Additionally, the size of print is often far from user-friendly for those of us extracting details.

I have conducted a brief survey using the 115 current periodicals received in the MRC Human Genetics Unit library, looking at the presence or absence of certain essential elements. An ideal standard' is the display of the volume number, the year, the part/issue number, the date, the ISSN, and the range of pages that the issue spans: the first four are most important for recording receipt. To take some examples: the European Journal of Immunology has no volume number on its front cover - it is on the spine; Byte has no volume number nor part number on the front cover -- they are on the spine; Laboratory Practice has no volume number nor part number on the front cover - it is on the inside; New Scientist has no volume number on the outside - - it is on the inside; Science has no part number on the front cover it is on the inside (two pages in). Scientific American has no volume number nor part number on the front cover they are on the inside (two pages in). Other, less important, deviations are the display of the ISSN number, date and span of pages.

Without wishing to detract from the freedom of design and individuality that periodicals should be allowed to have, is there any way that periodicals publishers could spare a thought for librarians?

MRC Human Genetics Unit,

SHEILA M. MOULD

Western General Hosptal,

Crewe Road,

Edinburgh EH4 2XU, UK

NATURE - VOL 354 - 5 DECEMBER 1991 